\title{
High gene flow in epiphytic ferns despite habitat loss and fragmentation
}

\author{
Manuela Winkler • Marcus Koch • Peter Hietz
}

Received: 1 May 2011 / Accepted: 10 June 2011/Published online: 2 July 2011

(c) The Author(s) 2011. This article is published with open access at Springerlink.com

\begin{abstract}
Tropical montane forests suffer from increasing fragmentation and replacement by other types of land-use such as coffee plantations. These processes are known to affect gene flow and genetic structure of plant populations. Epiphytes are particularly vulnerable because they depend on their supporting trees for their entire life-cycle. We compared population genetic structure and genetic diversity derived from AFLP markers of two epiphytic fern species differing in their ability to colonize secondary habitats. One species, Pleopeltis crassinervata, is a successful colonizer of shade trees and isolated trees whereas the other species, Polypodium rhodopleuron, is restricted to forests with anthropogenic separation leading to significant isolation between populations. By far most genetic variation was distributed within rather than among populations in both species, and a genetic admixture analysis did not reveal any clustering. Gene flow exceeded by far the benchmark of one migrant per generation to prevent genetic divergence between populations in both species. Though populations are threatened by habitat loss, long-distance dispersal is likely to support gene flow even between distant populations, which efficiently delays genetic isolation. Consequently, populations may rather be threatened by ecological consequences of habitat loss and fragmentation.
\end{abstract}

\footnotetext{
M. Winkler $(\bowtie) \cdot$ P. Hietz

Department of Integrative Biology, Institute of Botany, University of Natural Resources and Life Sciences (Boku), Gregor-Mendel-Str. 33, 1180 Vienna, Austria

e-mail: manuela.winkler@boku.ac.at

\section{Koch}

Department of Biodiversity and Plant Systematics, Centre for Organismal Studies (COS) Heidelberg, University of Heidelberg, Im Neuenheimer Feld 345,

69120 Heidelberg, Germany
}

Keywords Colonization - Epiphyte $\cdot$ Mexico · Pleopeltis crassinervata Polypodium rhodopleuron . Secondary habitats . Tropical montane forest

\section{Introduction}

Even if not leading to extinction, habitat loss and fragmentation can affect gene flow and the genetic structure of plant populations (Picó and Van Groenendael 2007). Both lead to reduced population size and increased spatial isolation usually resulting in an erosion of genetic variability (González-Astorga et al. 2004; Young et al. 1996). Possible causes are genetic bottlenecks and subsequently increased inbreeding in small populations, enhanced genetic drift and reduced gene flow (Templeton et al. 1990; Young et al. 1996). Several studies found that remnant population size was positively correlated with polymorphism and allelic richness (Cardoso et al. 2005; Morden and Loeffler 1999; Prober and Brown 1994; Van Treuren et al. 1991).

Whether and to which degree genetic consequences of fragmentation are detectable depends on the one hand on the time elapsed since the onset of fragmentation, and on the other hand on life-history traits of the concerned species. In recently fragmented populations often no effects on population genetic structure were found (reviewed in Aguilar et al. 2008; González-Astorga and Núñez-Farfán 2001; Murren 2003; Neel and Ellstrand 2001). Long-lived species and/or species with far-ranging pollination or seed dispersal syndromes like neotropical tree species (reviewed in Nason 2002) and epiphytic orchids (Ackerman and Ward 1999; Avila-Diaz and Oyama 2007; Bush et al. 1999; Trapnell and Hamrick 2004; Trapnell et al. 2004) exhibit high levels of genetic diversity and low genetic differentiation among populations even when they are separated by long distances. 
One of the terrestrial ecosystems most threatened by deforestation and fragmentation are tropical montane forests (Bruijnzeel et al. 2010). Despite their limited spatial extension they harbour a very diverse flora, e.g., Mexican tropical montane forests cover $<1 \%$ of the country's territory but contain between 10 and 12 percent of all Mexican vascular plant species with epiphytes representing a third of the plant species diversity in these forests (Williams-Linera 2007). In Mexico, less than one third of the area originally covered by tropical montane forests remained as closed forest by 1990 (Price and Butt 2003). Among the most extensive forms of land-use replacing tropical montane forests are coffee plantations. In Mexico, 770000 hectares were dedicated to the cultivation of coffee in 2007 (http://faostat.fao.org/site/567/default.aspx\#ancor), with coffee generally grown under shade trees (Moguel and Toledo 1999). Epiphytes depend on host trees for their entire life-cycle and are thus highly affected by deforestation and forest fragmentation (e.g., Padmawathe et al. 2004; Turner et al. 1994). Coffee plantations with large shade trees offer a refuge for many epiphytes in areas where few forests remain (García-Franco and ToledoAceves 2008; Mehltreter 2008), but not all species are able to colonize trees in secondary habitats (Hietz 2005).

In the present study we compare population genetic structure and genetic diversity of two epiphytic fern species differing in their ability to colonize secondary habitats (Mehltreter 2008). Pleopeltis crassinervata is a successful colonizer of isolated trees and shade trees in coffee plantations (Hooper and Haufler 1997). In contrast, Polypodium rhodopleuron is a shade-loving species, with sporophytes occurring preferentially in the lower parts of large tree trunks with dense bryophyte mats, in riparian forests or in the most humid parts of montane forests which are reduced to fragments with significant man-made isolation between populations today. Thus, the level of anthropogenic habitat loss and fragmentation is much more pronounced in Polypodium. Using highly reproducible and variable AFLP markers (Vos et al. 1995), we aim to discern between two scenarios: (1) High gene flow among populations prevents genetic consequences of fragmentation. In this case we expect high levels of genetic diversity and low levels of genetic divergence among populations. (2) The epiphytic ferns are sensitive to fragmentation with low levels of gene flow and genetic diversity and with most genetic variability located among populations.

\section{Materials and methods}

Study species

Polypodium rhodopleuron Kunze and Pleopeltis crassinervata (Fée) T. Moore are epiphytic ferns belonging to the family Polypodiaceae. Chromosome numbers are $2 n=74$ in Polypodium, and $2 n=70$ in Pleopeltis (Mickel and Smith 2004). Both species occur in tropical montane forests (classified as "bosque mesófilo de montaña" according to Rzedowski 1986) between 800-2100 (Polypodium) and 700-1900 m.s.m. (Pleopeltis; Mickel and Smith 2004). Polypodium has dry-deciduous leaves (Winkler et al. 2005), is restricted to the trunks and lower branches of forest trees (Tejero-Díez and Pacheco 2004) and is rare in the area with only a few known populations. By contrast, Pleopeltis can survive prolonged drought by curling its leathery, scaly leaves and is common in forests as well as on isolated trees and tree plantations (Hooper and Haufler 1997). Individual life spans are difficult to estimate, as both species possess creeping rhizomes. In Mexico, both species are distributed from the Sierra Madre Oriental to the Sierra Madre de Chiapas. Beyond Mexico, Polypodium occurs in Guatemala, Honduras and probably Nicaragua (TejeroDíez and Pacheco 2004), Pleopeltis is found south to Costa Rica (Mickel and Smith 2004). The study species belong to different lineages (Polypodium and Pleopeltis clade; Otto et al. 2009) of a large neotropical clade within the Polypodiaceae (Schneider et al. 2004). The relationship between the two lineages remains ambiguous (Otto et al. 2009).

\section{Sampling}

Polypodium and Pleopeltis were sampled from six and 17 localities, respectively, on the eastern slopes of the Sierra Madre Oriental around Xalapa, and additionally from one site (Los Tuxtlas) near the southern coast of the Gulf of Mexico in the Mexican state of Veracruz (Fig. 1; Table 1). For Polypodium these were all populations in the area we were able to find consulting herbarium registers and a local fern specialist (K. Mehltreter).

According to the most accurate survey data available (calculated from satellite-image data (Muñoz-Villers and López-Blanco 2007), forests, secondary habitats with trees (shaded coffee plantations, agroforestry) and nonarboreal vegetation (grassland, sugar cane and sun coffee plantations) covered about 21, 38 and $33 \%$, respectively, of the study area in central Veracruz in 2003 (Fig. 1). The mean size of forest patches was 1.06 ha (ranging between 0.04 and 2528 ha). Only between 1990 and 2003, a third of these forests were replaced by grassland and agricultural crops (Muñoz-Villers and López-Blanco 2007). In the Los Tuxtlas area, there are two larger and one smaller patch of humid montane forest on three isolated volcanoes, covering about 9600 ha in the core of the Los Tuxtlas Biosphere Reserve (Laborde 2004). The Los Tuxtlas mountains are separated from the Sierra 


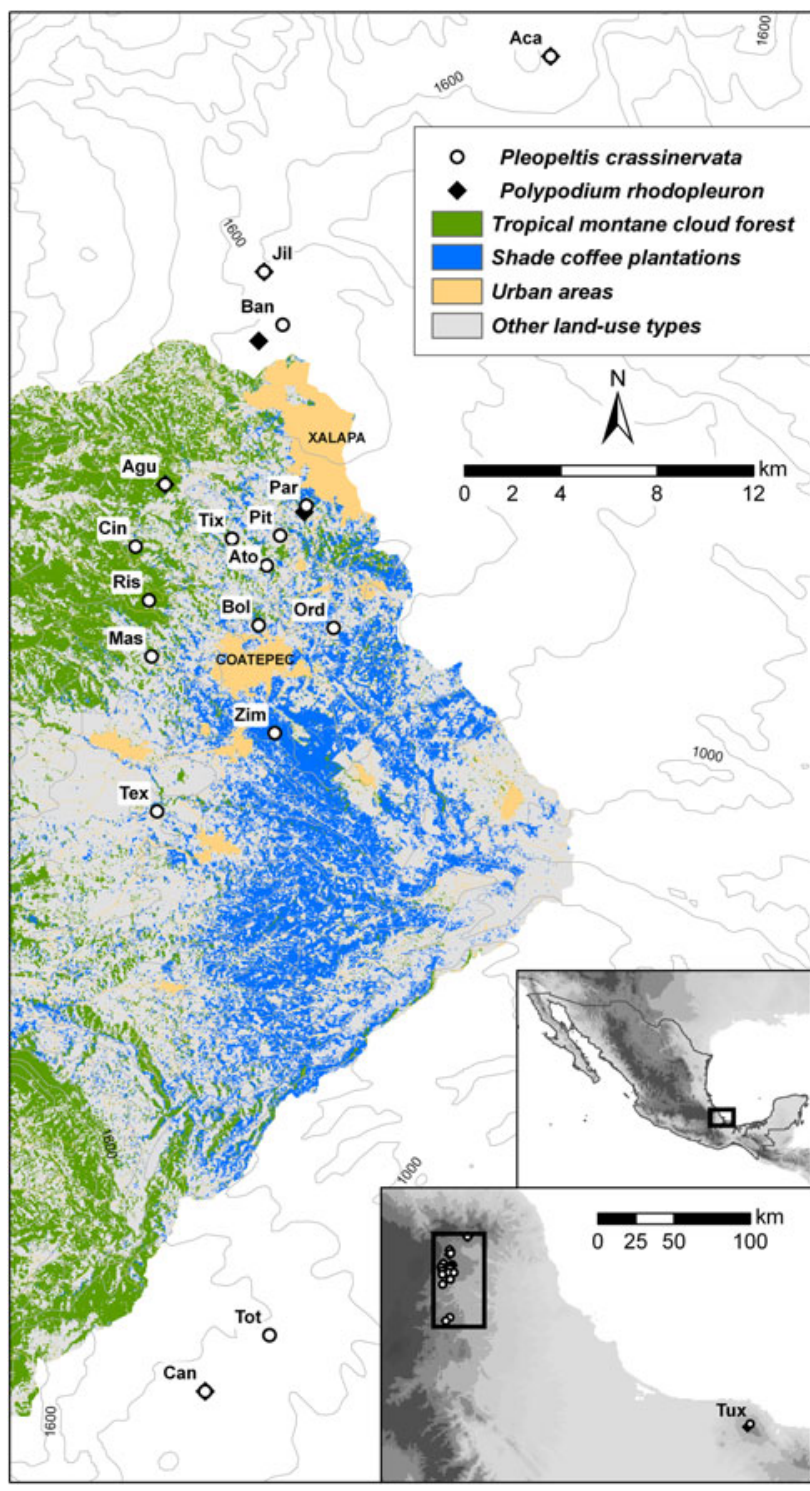

Fig. 1 Location of sampled populations of the epiphytic ferns Polypodium rhodopleuron and Pleopeltis crassinervata in Veracruz, Mexico. Land-use types are derived from satellite-images from the year 2003 (Muñoz-Villers and López-Blanco 2007). For white areas no landuse information was available. The lower inset shows the location of the Los Tuxtlas population (Tux). Contour lines were derived from the CONABIO (Comisión Nacional para el Conocimiento y Uso de la Biodiversidad) GIS portal http://www.conabio.gob.mx/informacion/ gis/, and GTOPO30 from the US Geological Survey (http://eros. usgs.gov/\#/Find_Data/Products_and_Data_Available/gtopo30_info)

Madre Oriental by about $200 \mathrm{~km}$ of coastal lowlands, where the two species do not occur.

Wherever possible, leaves of 15 individuals per site and located on different trees were collected, their surface cleaned from epiphylls and dried in silica gel. Voucher specimens were deposited at the herbarium of the Institute of Ecology, A.C. Mexico (XAL).

\section{DNA extraction and AFLP fingerprinting}

Total genomic DNA was extracted from similar amounts of dried tissue (ca. $20 \mathrm{mg}$ ) with the DNeasy 96 plant mini kit (Qiagen, Hilden, Germany) following the manufacturer's protocol. AFLP profiles were generated following established procedures (Vos et al. 1995) with minor modifications (Gugerli et al. 2008). Genomic DNA (ca. $200 \mathrm{ng}$ ) was digested with $1 \mathrm{U}$ MseI (New England BioLabs, Ipswich, USA) and $5 \mathrm{U}$ EcoRI (Promega, Madison, USA) and ligated (with 1.2 U of T4 DNA-Ligase; Promega) to double-stranded adapters in a thermal cycler (GeneAmp PCR System 9700; Applied Biosystems, Foster City, CA, USA) for $3 \mathrm{~h}$ at $37^{\circ} \mathrm{C}$. Preselective amplification was performed using primer pairs with a single selective nucleotide. Two selective primer combinations were chosen after a primer trial (fluorescent dye in brackets): EcoRI ATA (6-FAM)MseI CTG; EcoRI AGG (HEX)-MseI CAG (Pleopeltis), and EcoRI ATA (6-FAM)-MseI CTC; EcoRI AGG (HEX)MseI CTC (Polypodium). For each individual, $5 \mu \mathrm{l}$ of each selective PCR product was Sephadex-purified. $1 \mu \mathrm{l}$ of the purified product was combined with $0.25 \mu \mathrm{l} \mathrm{MegaBace} \mathrm{Et-}$ $550 \mathrm{R}$ (GE Healthcare) internal size standard and $4.75 \mu \mathrm{l}$ water, and separated on a capillary sequencer MegaBace 500 (GE Healthcare).

Blind samples were included to test for contamination. To test the reproducibility of AFLP fingerprinting, 20 plants of Polypodium were replicated between PCR plates, and seven samples of Polypodium and eight of Pleopeltis were replicated more than twice, resulting in a total of 55 and 168 replicates, respectively. The error rate was calculated as the number of mismatches divided by the number of phenotypical comparisons (Bonin et al. 2004).

Fragments in the range of $65-550$ bp were aligned, visualized, scored and exported as binary presence/absence matrix using DAx 8.1 (Van Mierlo Software Consultancy, The Netherlands).

\section{Analysis of AFLP data}

All monomorphic fragments and those present or absent in all minus the number of individuals corresponding to the error rate $\left(\mathrm{N}^{*}\right.$ error rate/100) were removed from the data set to avoid biased parameter estimates (Bonin et al. 2004). Seven individuals of Polypodium produced non-reproducible AFLP patterns and were excluded from analyses. We calculated the following statistics of genetic diversity at the population level:

(i) the number of fragments present in a population;

(ii) the number of private fragments restricted to a given population;

(iii) the proportion of polymorphic markers; 
Table 1 Characteristics of sampling locations, and genetic diversity and rarity estimates of populations of the epiphytic ferns Polypodium rhodopleuron and Pleopeltis crassinervata

\begin{tabular}{|c|c|c|c|c|c|c|c|c|c|}
\hline Population & Land-use type & $\begin{array}{l}\text { Forest } \\
\text { fragment } \\
\text { size (ha) }\end{array}$ & $\begin{array}{l}\text { Coordinates } \\
(\mathrm{W} / \mathrm{N})\end{array}$ & $N$ & $N_{\text {fragm }}$ & $N_{\text {priv }}$ & $P_{\text {poly }}$ & $H_{\mathrm{j}}( \pm \mathrm{SE})$ & $D W$ \\
\hline Polypodium rhodopleuron & & & & & & $\mathrm{b}$ & a & a & $\mathrm{b}$ \\
\hline Aca-Acatlán & Forest & $579^{1}$ & $96.85 / 19.68$ & 15 & 163 & 5 & 0.764 & $0.216 \pm 0.011$ & 1.088 \\
\hline Agu-Aguita Fría & Forest & $100^{4}$ & $96.95 / 19.60$ & 12 & 160 & 7 & 0.768 & $0.211 \pm 0.011$ & 1.039 \\
\hline Ban-Banderilla & Forest & $5^{4}$ & $96.96 / 19.58$ & 15 & 141 & 4 & 0.679 & $0.193 \pm 0.011$ & 0.87 \\
\hline Can-Las Cañadas & Forest & $299^{2}$ & $96.99 / 19.52$ & 12 & 172 & 10 & 0.801 & $0.244 \pm 0.011$ & 1.377 \\
\hline Jil-Jilotepec & Forest & $20^{4}$ & $96.94 / 19.51$ & 8 & 129 & 3 & 0.589 & $0.221 \pm 0.011$ & 1.105 \\
\hline Par-Parque Ecológico, INECOL & Forest & $32^{2}$ & $96.98 / 19.18$ & 14 & 143 & 2 & 0.642 & $0.182 \pm 0.011$ & 0.855 \\
\hline Tux-Los Tuxtlas & Forest & $9356^{3}$ & $95.20 / 18.56$ & 14 & 173 & 10 & 0.78 & $0.241 \pm 0.011$ & 1.488 \\
\hline Means & & & & & 154.4 & 5.9 & 0.718 & 0.215 & 1.117 \\
\hline Pleopeltis crassinervata & & & & & & a & a & $\mathrm{b}$ & $\mathrm{b}$ \\
\hline Aca-Acatlán & Forest & & $96.85 / 19.68$ & 15 & 144 & 0 & 0.673 & $0.218 \pm 0.012$ & 0.285 \\
\hline Agu-Aguita Fría & Forest & & $96.95 / 19.60$ & 14 & 165 & 0 & 0.774 & $0.267 \pm 0.012$ & 0.396 \\
\hline Ato-El Atorón & Shade coffee plantation & & $96.95 / 19.58$ & 15 & 157 & 0 & 0.744 & $0.255 \pm 0.013$ & 0.321 \\
\hline Ban-Banderilla & Forest & & $96.99 / 19.52$ & 14 & 165 & 0 & 0.769 & $0.276 \pm 0.012$ & 0.416 \\
\hline Bol-Bola de Oro & Shade coffee plantation & & $96.94 / 19.52$ & 15 & 164 & 0 & 0.754 & $0.265 \pm 0.012$ & 0.376 \\
\hline Can-Las Cañadas & Forest & & $96.97 / 19.50$ & 15 & 154 & 0 & 0.709 & $0.228 \pm 0.012$ & 0.305 \\
\hline Cin-Cinco Palos & Pasture & & $96.95 / 19.50$ & 14 & 162 & 1 & 0.769 & $0.249 \pm 0.013$ & 0.383 \\
\hline Jil-Jilotepec & Forest & & $96.95 / 19.49$ & 15 & 165 & 0 & 0.774 & $0.252 \pm 0.012$ & 0.374 \\
\hline Mas-La Mascota & Forest & & $97.00 / 19.50$ & 15 & 162 & 0 & 0.754 & $0.246 \pm 0.013$ & 0.362 \\
\hline Ord-La Orduña & Shade coffee plantation & & $97.00 / 19.48$ & 15 & 170 & 0 & 0.799 & $0.272 \pm 0.012$ & 0.428 \\
\hline Par-Parque Ecológico, INECOL & Forest & & $96.96 / 19.47$ & 15 & 165 & 0 & 0.754 & $0.269 \pm 0.012$ & 0.398 \\
\hline Pit-La Pitahaya & Shade coffee plantation & & $97.00 / 19.46$ & 15 & 153 & 0 & 0.683 & $0.241 \pm 0.012$ & 0.329 \\
\hline Ris-El Riscal & Forest & & $96.93 / 19.47$ & 15 & 161 & 1 & 0.754 & $0.262 \pm 0.012$ & 0.379 \\
\hline Tex-Texolo & Forest & & $96.95 / 19.43$ & 15 & 162 & 0 & 0.764 & $0.246 \pm 0.012$ & 0.331 \\
\hline Tix-Rancho Tixtla & Forest & & $96.99 / 19.40$ & 15 & 154 & 0 & 0.709 & $0.244 \pm 0.013$ & 0.325 \\
\hline Tot-Totutla & Forest & & $96.95 / 19.21$ & 15 & 164 & 0 & 0.769 & $0.260 \pm 0.012$ & 0.41 \\
\hline Tux-Los Tuxtlas & Forest & & $96.98 / 19.18$ & 15 & 172 & 2 & 0.789 & $0.265 \pm 0.012$ & 0.516 \\
\hline Zim-Zimpizahua & Shade coffee plantation & & $95.18 / 18.58$ & 15 & 163 & 0 & 0.749 & $0.252 \pm 0.012$ & 0.346 \\
\hline Means & & & & & 161.2 & 0.2 & 0.749 & 0.254 & 0.371 \\
\hline
\end{tabular}

Different lower-case letters indicate significant differences between species $(t$ test, $P<0.01)$, with a representing the lower and $\mathrm{b}$ the higher value, respectively

$N$ number of samples per population, $N_{\text {frag }}$ number of AFLP fragments in the population, $N_{\text {priv }}$ number of private fragments in the population, $P_{\text {poly }}$ proportion of polymorphic fragments in the population, $H_{\mathrm{j}}$ Nei's gene diversity, $D W$ within-population rarity of markers

${ }^{1}$ Derived from aerial photographs from the year 1993 (Williams-Linera et al. 2000)

2 (Manson et al. 2008)

${ }^{3}$ Derived from satellite images from the year 2000 (Mendoza et al. 2005)

${ }^{4}$ Estimation M. Winkler

(iv) the frequency of rare markers as frequency-downweighted marker values, calculated for each individual according to (Schönswetter and Tribsch 2005): $R_{x}=\sum_{i=1}^{n} \frac{s_{i x}}{\sum_{j=1}^{k} s_{i j}}$

where $n$ is the number of markers, $s_{i x}$ is the state of the $i$-th marker in individual $x$ (either 1 or 0 in AFLPs), and $k$ is the total number of individuals in the data set. In the denominator the number of occurrences of the $i$-th marker in the total data set is calculated. To control for differences in the number of markers, $R_{x}$ was divided by $n / 100$. Population values (in the following termed $D W$ ) were estimated as the average of the individual values. $D W$ is expected to be high in populations with a high frequency of rare markers, and is independent of the number of individuals. Calculations for $\mathrm{i}-\mathrm{iv}$ were carried out in $\mathrm{R}$ 
2.7.0 (R Development Core Team 2008) using functions "Diversity" and " $D W$ " in the R-script AFLPdat (Ehrich 2006); available from http://www.nhm.uio.no/english/ research/ncb/aflpdat/).

(v) Nei's gene diversity or expected heterozygosity $\left(H_{\mathrm{j}}\right.$; Nei 1987) calculated after estimating allele frequencies following (Lynch and Milligan 1994) using AFLPsurv 1.0 (Vekemans X. 2002, Laboratoire de Génétique et Ecologie Végétale, Université Libre de Bruxelles, Belgium; available from http://www.ulb. ac.be/sciences/lagev/aflp-surv.html).

Population genetic structure was investigated using the following:

(i) total gene diversity $\left(H_{\mathrm{t}}\right)$, i.e. expected heterozygosity or gene diversity in the overall sample; the average gene diversity within populations $\left(H_{\mathrm{w}}\right.$, mean of $H_{\mathrm{j}}$ already discussed above); the average gene diversity among populations in excess of that observed within populations $\left(H_{\mathrm{b}}\right.$; AFLPsurv 1.0$)$;

(ii) AMOVA (ARLEQUIN 3.11; Excoffier et al. 2005);

(iii) the proportion of total variation that is distributed among populations $\left(G_{\mathrm{ST}}\right.$; Nei 1973), calculated using Popgene 1.32 (Yeh and Boyle 1997); available from http://www.ualberta.ca/ fyeh/). Gene flow was estimated as $N m=0.5\left(1-G_{\mathrm{ST}}\right) / G_{\mathrm{ST}}$ (McDermott and McDonald 1993; Slatkin and Barton 1989) using Popgene 1.32.

(iv) The genetic covariance structure in the dataset was assessed within a graph theoretic framework (Population Graphs; Dyer 2007; Dyer and Nason 2004; available from http://dyerlab.bio.vcu.edu/software/), a model-free approach to demonstrating how genetic variation is distributed. In this network, populations are illustrated as nodes connected by edges if there is significant genetic covariance between the populations after removing the co-variation each population has with the remaining populations in the dataset. Normal edges are drawn where the physical distances are proportional to the genetic distances, compressed edges when they are closer, and extended edges when they are further apart than expected given the genetic distances $\left(\chi^{2}\right.$ tests at $\alpha=0.05$ significance level). Extended edges may indicate long-distance dispersal, whereas compressed edges point to the presence of topological, historical, or ecological sources of vicariance (Garrick et al. 2009). Populations not connected by an edge are significantly genetically isolated from each other. Mantel tests were conducted to test for correlations between the physical distance and graph distance matrices.
A principal co-ordinate analysis ( $\mathrm{PCoA}$ ) based on a matrix of Jaccard distances among individuals was calculated using the modules 'Dcenter' and 'Eigen' from NTSYS-pc 2.2 (Rohlf 1997). The software STRUCTURE v.2.2 (Falush et al. 2007; Pritchard et al. 2000) was employed to complement the distance-based analysis with a Bayesian clustering approach. We used an admixture model with uncorrelated allele frequencies and recessive alleles. Ten replicate runs for $K$ (number of groups) ranging from 1 to 10 were carried out at the Bioportal of the University of Oslo (http://www.bioportal.uio.no/), using a burn-in of 100,000 iterations followed by $1,000,000$ additional MCMC iterations. We identified the number of optimal groups as the value of $K$ where the increase in likelihood started to flatten out, the result of replicate runs was similar and the clusters were non-empty. The replicate runs of the best $K$ were then merged with CLUMPP 1.1.1. (Jakobsson and Rosenberg 2007) using the full-search algorithm.

\section{Results}

The two AFLP primer combinations yielded 246 and 199 clear polymorphic fragments after the removal of ten and eleven invariable markers in Polypodium and Pleopeltis, respectively. In the AFLP profiles from replicated samples, 777 differences were observed out of 20,515 phenotypic comparisons, resulting in an error rate of $3.79 \%$ in $\mathrm{Po}$ lypodium, and of $3.72 \%$ in Pleopeltis (1,550 differences, 41,664 comparisons). All phenotypes of both species were unique. There were no significant differences in the proportion of polymorphic markers $\left(P_{\text {poly }}\right)$ between Polypodium and Pleopeltis. Genetic diversity $\left(H_{\mathrm{j}}\right)$ was significantly higher in populations of Pleopeltis compared to Polypodium, whereas genetic rarity $(D W)$ and the number of private markers $\left(N_{\text {priv }}\right)$ were significantly higher in Polypodium ( $t$ tests, $P<0.01$; Table 1).

There was no significant correlation of $H_{\mathrm{j}}$, the $P_{\text {poly }}, N_{\text {priv }}$ or $D W$ with forest fragment size in Polypodium (Spearman rank correlation, all $P>0.05$ ). Of the measures of genetic diversity and rarity, only $H_{\mathrm{j}}$ and $D W(\rho=0.96, P<0.001)$, and $N_{\text {priv }}$ and $P_{\text {poly }}(\rho=0.96, P<0.001)$ were significantly correlated. In Pleopeltis, $H_{\mathrm{j}}$ and $P_{\text {poly }}(\rho=0.69$, $P<0.001), H_{\mathrm{j}}$ and $D W(\rho=0.85, P<0.001)$, and $D W$ and $P_{\text {poly }}(\rho=0.85, P<0.001)$ were correlated, respectively.

Within-population variation contributed at least $89.5 \%$ to overall genetic variation in Polypodium, and $92.1 \%$ in Pleopeltis $\left(G_{\mathrm{ST}}, F_{\mathrm{ST}}, H_{\mathrm{w}}\right.$; Table 2$)$. In the Population Graphs network of both species, the distant Tux population was connected with two central Veracruz populations each by extended edges indicating long-distance dispersal (Fig. 2). The covariance structure of central Veracruz 
Table 2 Partitioning of genetic diversity within and among populations of the epiphytic ferns Polypodium rhodopleuron and Pleopeltis crassinervata

\begin{tabular}{|c|c|c|c|c|c|c|c|c|c|c|c|}
\hline \multirow[t]{2}{*}{$H_{\mathrm{t}}$} & \multirow[t]{2}{*}{$H_{\mathrm{w}}$} & \multirow[t]{2}{*}{$H_{\mathrm{b}}$} & \multirow[t]{2}{*}{$G_{\mathrm{ST}}$} & \multirow[t]{2}{*}{$\mathrm{Nm}$} & \multicolumn{7}{|l|}{ AMOVA } \\
\hline & & & & & Source of variation & d.f. & $\begin{array}{l}\text { Sum of } \\
\text { squares }\end{array}$ & $\begin{array}{l}\text { Components } \\
\text { of variance }\end{array}$ & $\begin{array}{l}\text { Percentage } \\
\text { variation }\end{array}$ & $F_{\mathrm{ST}}$ & $P$ \\
\hline \multicolumn{12}{|c|}{ Polypodium rhodopleuron } \\
\hline \multirow[t]{3}{*}{0.223} & $0.215 \pm 0.009$ & $0.008 \pm 0.001$ & 0.105 & 4.263 & Among populations & 6 & 363.2 & 2.4 & 7.7 & 0.077 & $<0.001$ \\
\hline & & & & & Within populations & 83 & 2427.5 & 29.2 & 92.3 & & \\
\hline & & & & & Total & 89 & 2790.7 & 31.7 & & & \\
\hline \multicolumn{12}{|c|}{ Pleopeltis crassinervata } \\
\hline \multirow[t]{3}{*}{0.257} & $0.254 \pm 0.004$ & $0.003 \pm 0.001$ & 0.079 & 5.815 & Among populations & 17 & 638.8 & 0.8 & 3.2 & 0.031 & $<0.001$ \\
\hline & & & & & Within populations & 249 & 6312.7 & 25.4 & 96.9 & & \\
\hline & & & & & Total & 266 & 6951.5 & 26.2 & & & \\
\hline
\end{tabular}

$H_{\mathrm{t}}$ total gene diversity, $H_{\mathrm{w}}$ average gene diversity within populations, $H_{\mathrm{b}}$ average gene diversity among populations in excess of that observed within populations, $G_{\mathrm{ST}}$ proportion of total variation that is distributed among populations (Nei 1973), $\mathrm{Nm}$, gene flow estimated as $\mathrm{Nm}=$ $0.5\left(1-G_{\mathrm{ST}}\right) / G_{\mathrm{ST}}($ McDermott and McDonald 1993; Slatkin and Barton 1989); results of AMOVA

Fig. 2 Population graphs network (Dyer and Nason 2004) illustrating the genetic covariance structure in Mexican populations of the epiphytic ferns Polypodium rhodopleuron (a), and Pleopeltis crassinervata (b). Populations are connected by edges if their genetic structures are conditionally dependent. Normal edges (black lines) are those where the physical distances are proportional to the genetic distances. If they are not, then the populations are either closer (compressed edges, blue lines) or further apart (extended edges, red lines) than expected given the genetic distances
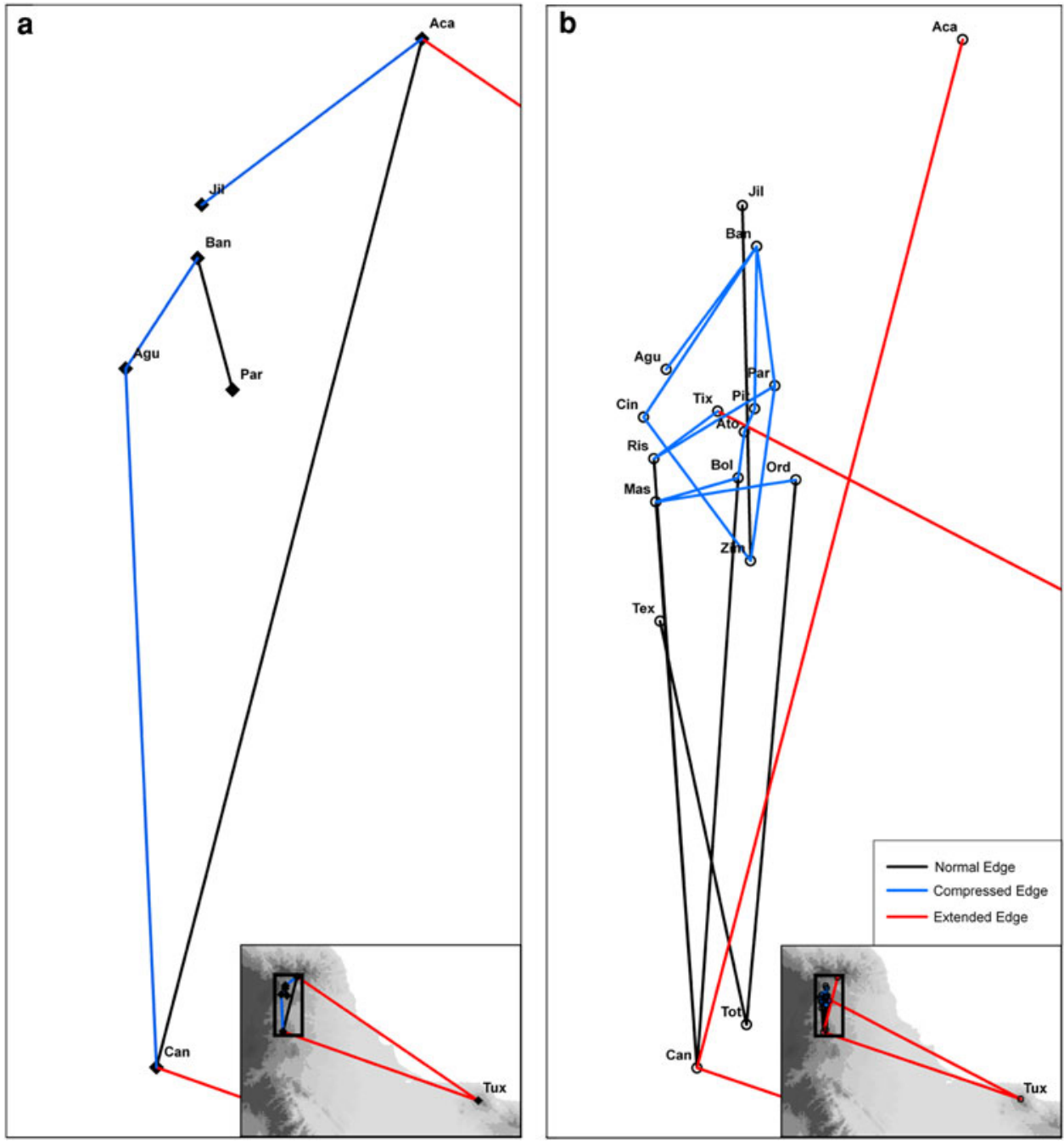
populations was characterized by compressed and normal edges (with the exception of one extended edge in Pleopeltis). Geographically close Pleopeltis population pairs were either not connected or by compressed edges. Graph distances and physical distances were not correlated (Mantel tests; Polypodium: $R=0.02, P=0.418$; Pleopeltis: $R=0.06, P=0.272$ ).

Both the distance-based approach (PCoA; Fig. 3) and the Bayesian clustering approach (STRUCTURE) showed no substructure in the dataset of both species. The optimal number of groups in STRUCTURE was $K=1$ in both species, because there were empty clusters in $\mathrm{K}=2$ to $\mathrm{K}=10$ (data not shown).
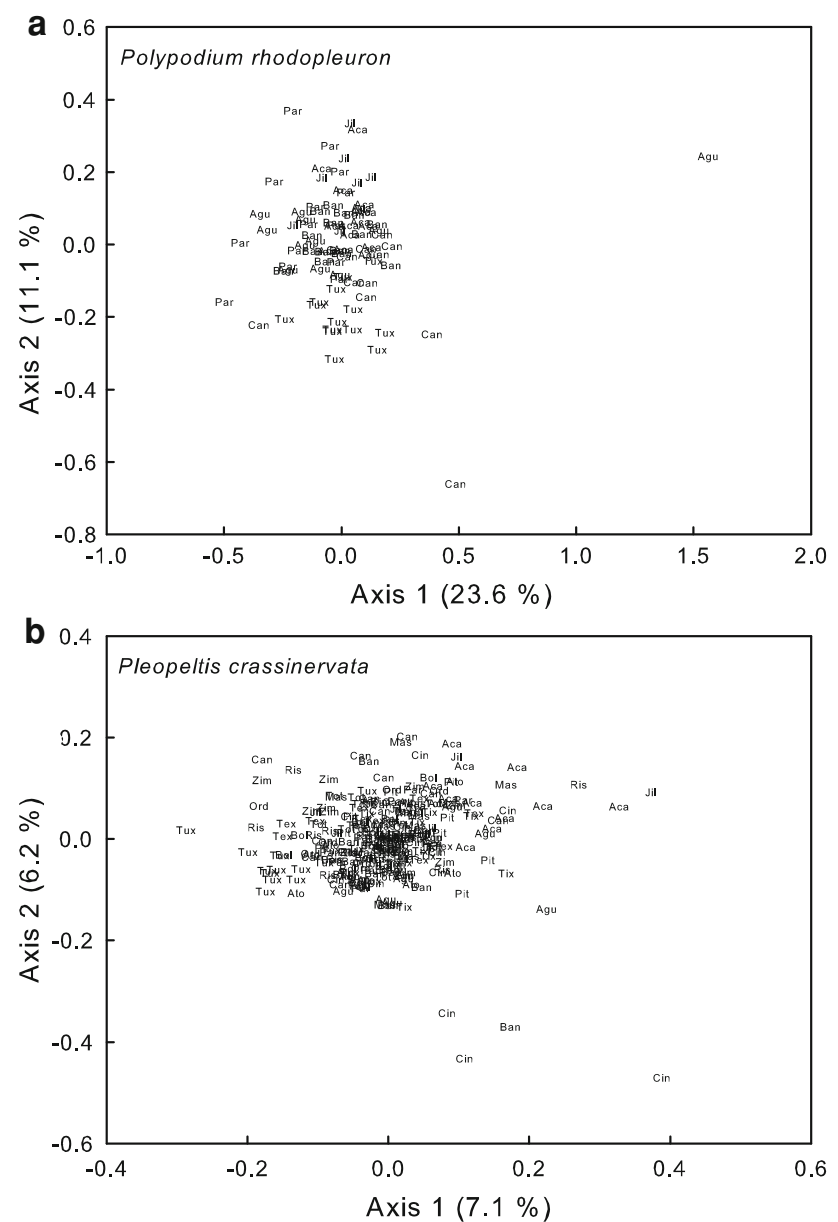

Fig. 3 Principal coordinate analysis of a matrix pair-wise Jaccard distances derived from AFLP analysis of Mexican populations of the epiphytic ferns Polypodium rhodopleuron (a), and Pleopeltis crassinervata (b). The first ordination axis explains 23.6 and $7.1 \%$, and the second 11.1 and $6.2 \%$ of the variation in the data matrix for Polypodium and Pleopeltis, respectively. Three-letter codes indicate sampling populations (see Table 1)

\section{Discussion}

Genetic consequences of man-made habitat fragmentation

Despite being affected by different degrees of habitat loss and fragmentation, both the colonizing and the forest fern exhibited high genetic diversity and low differentiation from which we infer that levels of contemporary gene flow are high. The number of migrants per generation $(\mathrm{Nm})$ in both ferns by far exceeded the benchmark of one migrant per generation as a minimum to prevent genetic divergence (Slatkin 1985; Wright 1931; Table 2). These results suggest that populations of both species were sufficiently connected by gene flow to prevent genetic divergence. Although indirect $N m$ estimation from $F_{\mathrm{ST}}$ or $G_{\mathrm{ST}}$ probably violates several assumptions of the underlying model, $\mathrm{Nm}$ values may be correct within a few orders of magnitude (Whitlock and McCauley 1999) and thus constitute a useful and widely used measure of overall gene flow levels for comparisons with other species. Our gene flow estimates are in the range of those recorded for 25 terrestrial and epiphytic fern species (reviewed in Ranker and Geiger 2008). Interestingly, none of the epiphytic species in this compilation had a $\mathrm{Nm}$ value $<1$. In agreement with high levels of interpopulational gene flow (historic or recent) no clustering of populations was detected in either species (Fig. 2; optimal $K=1$ in STRUCTURE) - not even the Los Tuxtlas populations at a distance of about $200 \mathrm{~km}$ were grouped separately but were connected with central Veracruz via long-distance dispersal (Fig. 2). Furthermore, most genetic variability by far was located within rather than among populations (Table 2) with no isolation by distance (Mantel-tests).

Our study confirms the notion that ferns are exceptionally good at long-distance dispersal. Their dust-like spores have been found in the jet streams (e.g., Caulton et al. 2000), and are capable of surviving intense UV radiation and low temperatures in the upper atmosphere (Gradstein and Van Zanten 1999). As a result, ferns are often among the first plants to colonize new habitats, often repeatedly (Ranker et al. 1994), and are overrepresented in island floras (Kessler 2010; Ranker and Geiger 2008).

Human impact was comparatively moderate in the study area until the end of the 19th century when coffee plantations began to replace montane forests. In the 1960s demographic pressure in the region around Xalapa increased dramatically and rates of forest destruction and conversion to pastures accelerated (Marchal and Palma 1985). Today, about $20 \%$ of our study area is still covered by tropical montane forest (Muñoz-Villers and López-Blanco 2007; Fig. 1), but less than half of these fragments can be considered as undisturbed (CONABIO 2010; Williams-Linera 2002) and are 
thus suitable habitat for Polypodium. The habitat of Pleopeltis, in contrast, is disrupted in those $40 \%$ of the study area only, where no trees are available at all (Muñoz-Villers and López-Blanco 2007; Fig. 1).

Still, Polypodium retains high genetic diversity (mean expected heterozygosity $H_{\mathrm{t}}=0.223$ ) compared to the mean reported for 486 seed plants $\left(H_{\mathrm{e}}=0.113\right.$; Hamrick and Godt 1990), terrestrial ferns $\left(H_{\mathrm{e}}=0.117\right)$, or other epiphytic ferns $\left(H_{\mathrm{e}}=0.149\right.$; reviewed in Ranker and Geiger 2008), and was little lower than in the successful colonizer Pleopeltis $\left(H_{\mathrm{t}}=0.257\right)$. Krauss (2000) showed that genetic diversity estimates from dominant marker data derived with a method introduced by Lynch and Milligan (1994) are accurate in outcrossing species, therefore estimates should be comparable to the allozyme data from the studies cited above. Furthermore, expected heterozygosity for Pleopeltis obtained with AFLP fingerprinting (0.254) was nearly identical to the value obtained using allozymes (0.252; Hooper and Haufler 1997). Breeding systems of both species help maintain high levels of genetic diversity in small and isolated populations. Pleopeltis crassinervata was shown to be outcrossing (Hooper and Haufler 1997). For Polypodium rhodopleuron, no information on breeding system is available, but all epiphytic fern species presented in a review by Ranker and Geiger (2008) are outcrossing.

Despite weak genetic structure and evidence for high gene flow in both species there are subtle differences in the distribution of rare markers. $D W$ and the number of private fragments were significantly higher in populations of the forest species compared to the colonizer with most rare markers present in Los Tuxtlas, the remotest population, in both species (Table 1). A high proportion of rare markers can be explained in two ways: First, rare markers accumulate in fragmented populations due to mutations. This scenario appears unlikely because not enough time has elapsed since fragmentation (ca. 50 years, which translates into very few generations in a long-lived species; Aguilar et al. 2008) to produce the observed genetic rarity levels, especially given the high level of gene flow, via mutations. The Los Tuxtlas population is the only exception because the surrounding lowlands do not constitute suitable habitat for the fern species suggesting a longer-lasting isolation of this particular population. Neither $D W$ nor the number of private fragments were negatively correlated with fragment size, on the contrary, the measures of genetic rarity were highest in the largest forest patches and increased significantly with increasing genetic diversity. Furthermore, genetic drift in small remnant populations puts rare markers at a greater risk of disappearing than frequent ones (Frankham et al. 2002; Young et al. 1996). Secondly, genetic rarity is expected to be high in long-term isolated populations (Schönswetter and Tribsch 2005), suggesting that populations of Polypodium have been more isolated than those of Pleopeltis already before anthropogenic habitat fragmentation due to differing habitat requirements. Suitable habitat for Polypodium may have been patchy and restricted to the most humid parts of continuous forests of the past.

\section{Conservation messages}

Anthropogenic habitat fragmentation so far had no apparent effect on genetic diversity of an epiphyte restricted to forests compared to a widespread species thriving in secondary habitats. In determining the genetic effects of fragmentation, plant longevity, mating system and ability for dispersal play an important role (Hamrick and Godt 1996). Similar to tropical trees (Nason 2002), epiphytes seem to be more resistant to adverse genetic consequences of habitat fragmentation (e.g., Alcantara et al. 2006; AvilaDiaz and Oyama 2007; Murren 2003; but see GonzálezAstorga et al. 2004) than terrestrial herbs. Most epiphytes are wind-dispersed (Benzing 1990), and especially epiphytic ferns and orchids with their dust-like diaspores can bridge even long distances between remnant forest patches, which efficiently reduces genetic isolation. As both study species are also rhizomatous and long-lived, genetic consequences of fragmentation may in fact be delayed and only visible after several generations (Kramer et al. 2008).

Not genetic but ecological consequences of habitat loss and forest fragmentation might be crucial (Kramer et al. 2008; Lande 1988) for the fate of Polypodium populations. Microclimatic conditions in secondary habitats (Scheffknecht et al. 2010) and forest fragment edges (Murcia 1995) are drier compared to the interior of undisturbed forests. Epiphytes growing in exposed positions in the crowns of forest trees like Pleopeltis are supposed to be better adapted to these conditions than shade-loving and droughtsensitive species such as Polypodium (Hietz 2010). If the availability of safe sites for recruitment declines, population sizes will decrease, eventually leading to Allee effects and demographic stochasticity (Lande 1988; Ouborg et al. 2006). Therefore, conservation efforts should not be limited to preserve as many forests as possible but should also aim at preventing the deterioration of these fragments.

Acknowledgments We appreciate the comments of Karl Hülber, the editor and two anonymous reviewers on an earlier version of the manuscript. Klaus Mehltreter kindly helped to locate Polypodium rhodopleuron sites and identified herbarium specimens. We thank Susanne Scheffknecht, Jesús Eduardo Martínez Leyva and Alejandro Hernández Sánchez for assisting collection trips. The Instituto de Ecología in Xalapa, in particular Claudia Gallardo Hernández, José García Franco and the herbarium provided general support. Peter Schönswetter and Matthias Kropf gave valuable technical advice on AFLPs. Lyssette Muñoz-Villers kindly provided land-use type information for parts of the study area and Dietmar Moser calculated forest patch areas. This research was funded by the Austrian Science Fund (FWF grant P17875). 
Open Access This article is distributed under the terms of the Creative Commons Attribution Noncommercial License which permits any noncommercial use, distribution, and reproduction in any medium, provided the original author(s) and source are credited.

\section{References}

Ackerman JD, Ward S (1999) Genetic variation in a widespread, epiphytic orchid: where is the evolutionary potential? Syst Bot 24:282-291

Aguilar R, Quesada M, Ashworth L, Herrerias-Diego Y, Lobo J (2008) Genetic consequences of habitat fragmentation in plant populations: susceptible signals in plant traits and methodological approaches. Mol Ecol 17:5177-5188

Alcantara S, Semir J, Solferini VN (2006) Low genetic structure in an epiphytic Orchidaceae (Oncidium hookeri) in the Atlantic rainforest of South-eastern Brazil. Ann Bot 98:1207-1213

Avila-Diaz I, Oyama K (2007) Conservation genetics of an endemic and endangered epiphytic Laelia speciosa (Orchidaceae). Am J Bot 94:184-193

Benzing DH (1990) Vascular epiphytes. General biology and related biota. Cambridge University Press, Cambridge

Bonin A, Bellemain E, Bronken Eidesen P, Pompanon F, Brochmann C, Taberlet P (2004) How to track and assess genotyping errors in population genetics studies. Mol Ecol 13:3261-3273

Bruijnzeel LA, Scatena FN, Hamilton LS (eds) (2010) Tropical Montane cloud forests: science for conservation and management. Cambridge University Press, Cambridge

Bush SP, Kutz WE, Anderton JM (1999) RAPD variation in temperate populations of the epiphytic orchid Epidendrum conopseum and the epiphytic fern Pleopeltis polypodioides. Selbyana 20:120-124

Cardoso SRS, Provan J, Lira CDF, Pereira LDOR, Ferreira PCG, Cardoso MA (2005) High levels of genetic structuring as a result of population fragmentation in the tropical tree species $\mathrm{Cae}$ salpinia echinata Lam. Biodivers Conserv 14:1047-1057

Caulton E, Keddie S, Carmichael R, Sales J (2000) A ten year study of the incidence of spores of bracken (Pteridium aquilinum (L.) Kuhn.) in an urban rooftop airstream in south east Scotland. Aerobiologia 16:29-33

CONABIO (2010) El Bosque Mesófilo de Montaña en México: Amenazas y Oportunidades para su Conservación y Manejo Sostenible. Comisión Nacional para el Conocimiento y Uso de la Biodiversidad, México

Dyer RJ (2007) The evolution of genetic topologies. Theor Popul Biol 71:71-79

Dyer RJ, Nason JD (2004) Population graphs: the graph theoretic shape of genetic structure. Mol Ecol 13:1713-1727

Ehrich D (2006) AFLPdat: a collection of R functions for convenient handling of AFLP data. Mol Ecol Notes 6:603-604

Excoffier L, Laval G, Schneider S (2005) Arlequin version 3.0: an integrated software package for population genetics data analysis. Evolut Bioinformatics Online 1:47-50

Falush D, Stephens M, Pritchard JK (2007) Inference of population structure using multilocus genotype data: dominant markers and null alleles. Mol Ecol Notes 7:574-578

Frankham R, Ballou JD, Briscoe DA (2002) Introduction to conservation genetics. Cambridge University Press, Cambridge

García-Franco JG, Toledo-Aceves T (2008) Epífitas vasculares: bromelias y orquídeas. In: Manson RH, Hernández-Ortiz V, Gallina S, Mehltreter K (eds) Agroecosistemas Cafetaleros de Veracruz: Biodiversidad, Manejo y Conservación. Instituto de Ecología A.C. (INECOL) \& Instituto Nacional de Ecología (INE-SEMARNAT), Mexico, pp 69-82
Garrick RC, Nason JD, Meadows CA, Dyer RJ (2009) Not just vicariance: phylogeography of a Sonoran Desert euphorb indicates a major role of range expansion along the Baja peninsula. Mol Ecol 18:1916-1931

González-Astorga J, Núñez-Farfán J (2001) Effect of habitat fragmentation on the genetic structure of the narrow endemic Brongniartia vazquezii. Evol Ecol Res 3:861-872

González-Astorga J, Cruz-Angón A, Flores-Palacios A, Vovides AP (2004) Diversity and genetic structure of the Mexican endemic epiphyte Tillandsia achyrostachys E. Morr. ex Baker var. achyostachys (Bromeliaceae). Ann Bot 94:545-551

Gradstein SR, Van Zanten BO (1999) High altitude dispersal of spores: an experimental approach. In: Abstracts of the XVI international botanical congress, St. Louis, 1999

Gugerli F, Englisch T, Niklfeld H, Tribsch A, Mirek Z, Ronikier M, Zimmermann NE, Holderegger R, Taberlet P (2008) Relationships among levels of biodiversity and the relevance of intraspecific diversity in conservation-a project synopsis. Perspect Plant Ecol Evol Syst 10:259-281

Hamrick JL, Godt MJW (1990) Allozyme diversity in plant species. In: Brown AHD, Clegg MT, Kahler AL, Weir BS (eds) Plant population genetics, breeding, and genetic resources. Sinauer, Sunderland, pp 43-63

Hamrick JL, Godt MJW (1996) Effects of life history traits on genetic diversity in plant species. Philos Trans R Soc Lond Ser B 351:1291-1298

Hietz P (2005) Conservation of vascular epiphyte diversity in Mexican coffee plantations. Conserv Biol 19:391-399

Hietz P (2010) Fern adaptations to xeric environments. In: Mehltreter K, Walker LR, Sharpe JM (eds) Fern ecology. Cambridge University Press, Cambridge, pp 140-176

Hooper EA, Haufler CH (1997) Genetic diversity and breeding system in a group of neotropical epiphytic ferns (Pleopeltis; Polypodiaceae). Am J Bot 84:1664-1674

Jakobsson M, Rosenberg NA (2007) CLUMPP: a cluster matching and permutation program for dealing with label switching and multimodality in analysis of population structure. Bioinformatics 23:1801-1806

Kessler M (2010) Biogeography of ferns. In: Mehltreter K, Walker LR, Sharpe JM (eds) Fern ecology. Cambridge University Press, Cambridge, pp 22-60

Kramer AT, Ison JL, Ashley MV, Howe HF (2008) The paradox of forest fragmentation genetics. Conserv Biol 22:878-885

Krauss SL (2000) Accurate gene diversity estimates from amplified fragment length polymorphism (AFLP) markers. Mol Ecol 9:1241-1245

Laborde J (2004) La Reserva de la Biosfera. In: Guevara S, Laborde J, Sánchez-Ríos G (eds) Los Tuxtlas: El paisaje de la sierra. Instituto de Ecología, Xalapa, pp 271-279

Lande R (1988) Genetics and demography in biological conservation. Science 241:1455-1460

Lynch M, Milligan BG (1994) Analysis of population genetic structure with RAPD markers. Mol Ecol 3:91-99

Manson RH, Hernández-Ortiz V, Gallina S, Mehltreter K (eds) (2008) Agroecosistemas Cafetaleros de Veracruz: Biodiversidad, Manejo y Conservación. Instituto de Ecología A.C. (INECOL) \& Instituto Nacional de Ecología (INE-SEMARNAT), Mexico

Marchal JY, Palma R (1985) Análisis gráfico de un espacio regional: Veracruz. INIREB-ORSTOM, Xalapa

McDermott JM, McDonald BA (1993) Gene flow in plant pathosystems. Annu Rev Phytopathol 31:353-373

Mehltreter K (2008) Helechos. In: Manson RH, Hernández-Ortiz V, Gallina S, Mehltreter K (eds) Agroecosistemas Cafetaleros de Veracruz: Biodiversidad, Manejo y Conservación. Instituto de Ecología A.C. (INECOL) \& Instituto Nacional de Ecología (INE-SEMARNAT), Mexico, pp 83-94 
Mendoza E, Fay J, Dirzo R (2005) A quantitative analysis of forest fragmentation in Los Tuxtlas, southeast Mexico: patterns and implications for conservation. Rev Chil Hist Nat 78:451-467

Mickel JT, Smith AR (2004) The pteridophytes of Mexico. Part I (Descriptions and maps). New York Botanical Garden, New York

Moguel P, Toledo VM (1999) Biodiversity conservation in traditional coffee systems of Mexico. Conserv Biol 13:11-21

Morden CW, Loeffler W (1999) Fragmentation and genetic differentiation among subpopulations of the endangered Hawaiian mint Haplostachys haplostachya (Lamiaceae). Mol Ecol 8:617-625

Muñoz-Villers LE, López-Blanco J (2007) Land use/cover changes using Landsat TM/ETM images in a tropical and biodiverse mountainous area of central-eastern Mexico. Int J Remote Sens 29:71-93

Murcia C (1995) Edge effects in fragmented forests: implications for conservation. Trends Ecol Evol 10:58-62

Murren CJ (2003) Spatial and demographic population genetic structure in Catasetum viridiflavum across a human-disturbed habitat. J Evol Biol 16:333-342

Nason JD (2002) La estructura genética de las poblaciones de árboles. In: Guariguata MR, Kattan GH (eds) Ecología y conservación de bosques neotropicales. Ediciones LUR, Cartago, pp 299-327

Neel MC, Ellstrand NC (2001) Patterns of allozyme diversity in the threatened plant Erigeron parishii (Asteraceae). Am J Bot $88: 810-818$

Nei M (1973) Analysis of gene diversity in subdivided populations. Proc Natl Acad Sci 70:3321-3323

Nei M (1987) Molecular evolutionary genetics. Columbia University Press, New York

Otto EM, Janßen T, Kreier H-P, Schneider H (2009) New insights into the phylogeny of Pleopeltis and related Neotropical genera (Polypodiaceae, Polypodiopsida). Mol Phylogen Evol 53:190-201

Ouborg NJ, Vergeer P, Mix C (2006) The rough edges of the conservation genetics paradigm for plants. J Ecol 94:1233-1248

Padmawathe R, Qureshi Q, Rawat GS (2004) Effects of selective logging on vascular epiphyte diversity in a moist lowland forest of Eastern Himalaya, India. Biol Conserv 119:81-92

Picó FX, Van Groenendael J (2007) Large-scale plant conservation in European semi-natural grasslands: a population genetic perspective. Divers Distrib 13:920-926

Price MF, Butt N (2003) Forests in sustainable mountain development. A state of knowledge report for 2000. CABI Publishing, Wallingford

Pritchard JK, Stephens M, Donnelly P (2000) Inference of population structure using multilocus genotype data. Genetics 155:945-959

Prober SM, Brown AHD (1994) Conservation of the grassy white box woodlands: population genetics and fragmentation of Eucalyptus albens. Conserv Biol 8:1003-1013

R Development Core Team (2008) R: a language and environment for statistical computing. R Foundation for Statistical Computing, Vienna

Ranker TA, Geiger JMO (2008) Population genetics. In: Ranker TA, Haufler CH (eds) Biology and evolution of ferns and lycophytes. Cambridge University Press, Cambridge, pp 107-133

Ranker TA, Floyd SK, Trapp PG (1994) Multiple colonizations of Asplenium adiantum-nigrum onto the Hawaiian archipelago. Evolution 48:1364-1370

Rohlf FJ (1997) NTSYS-pc: numerical taxonomy and multivariate analysis system, Version 2.0.2. Exeter Software, Setauket

Rzedowski J (1986) Vegetación de México, 3rd edn. Editorial Limusa, Mexico D.F

Scheffknecht S, Winkler M, Hülber K, Rosas MM, Hietz P (2010) Seedling establishment of epiphytic orchids in forests and coffee plantations in Central Veracruz, Mexico. J Trop Ecol 26:93-102
Schneider H, Smith AR, Cranfill R, Hildebrand TJ, Haufler CH, Ranker TA (2004) Unraveling the phylogeny of polygrammoid ferns (Polypodiaceae and Grammitidaceae): exploring aspects of the diversification of epiphytic plants. Mol Phylogen Evol 31:1041-1063

Schönswetter P, Tribsch A (2005) Vicariance and dispersal in the alpine perennial Bupleurum stellatum L. (Apiaceae). Taxon $54: 725-732$

Slatkin M (1985) Gene flow in natural populations. Annu Rev Ecol Syst 16:393-430

Slatkin M, Barton NH (1989) A comparison of three indirect methods for estimating average levels of gene flow. Evolution 43:1349-1368

Tejero-Díez JD, Pacheco L (2004) Notas taxonómicas y de distribución en Polypodium plesiosorum y P. rhodopleuron (Polypodiaceae: Pteridophyta) Anales del Instituto de Biología, Universidad Nacional Autónoma de México. Ser Botánica 75:11-37

Templeton AR, Shaw K, Routman E, Davis SK (1990) The genetic consequences of habitat fragmentation. Ann Mo Bot Gard $77: 13-27$

Trapnell DW, Hamrick JL (2004) Partitioning nuclear and chloroplast variation at multiple spatial scales in the neotropical epiphytic orchid, Laelia rubescens. Mol Ecol 13:2655-2666

Trapnell DW, Hamrick JL, Nason JD (2004) Three-dimensional finescale genetic structure of the neotropical epiphytic orchid, Laelia rubescens. Mol Ecol 13:1111-1118

Turner IM, Tan HTW, Wee YC, Ibrahim AB, Chew PT, Corlett RT (1994) A study of plant species extinction in Singapore: lessons for the conservation of tropical biodiversity. Conserv Biol 8:705-712

Van Treuren R, Bijlsma R, van Delden W, Ouborg NJ (1991) The significance of genetic erosion in the process of extinction. I. Genetic differentiation in Salvia pratensis and Scabiosa columbaria in relation to population size. Heredity 66:181-189

Vos P, Hogers R, Bleeker M, Reijans M, VanDeLee T, Hornes M, Frijters A, Pot J, Peleman J, Kuiper M, Zabeau M (1995) AFLP: a new technique for DNA fingerprinting. Nucleic Acids Res 23:4407-4414

Whitlock MC, McCauley DE (1999) Indirect measures of gene flow and migration: FST $\neq 1 /(4 \mathrm{Nm}+1)$. Heredity $82: 117-125$

Williams-Linera G (2002) Tree species richness complementarity, disturbance and fragmentation in a Mexican tropical montane cloud forest. Biodivers Conserv 11:1825-1843

Williams-Linera G (2007) El bosque de niebla del centro de Veracruz: ecología, historia, y destino en tiempos de fragmentación y cambio climático. Instituto de Ecología A.C, CONABIO, Xalapa

Williams-Linera G, Devall MS, Alvarez-Aquino C (2000) A relict population of Fagus grandifolia var. mexicana at the Acatlan Volcano, Mexico: structure, litterfall, phenology and dendroecology. J Biogeogr 27:1297-1309

Winkler M, Hülber K, Mehltreter K, García-Franco J, Hietz P (2005) Herbivory in epiphytic bromeliads, orchids and ferns in a Mexican humid montane forest. J Trop Ecol 21:147-154

Wright S (1931) Evolution in Mendelian populations. Genetics 16:97-159

Yeh FC, Boyle TJB (1997) Population genetic analysis of codominant and dominant markers and quantitative traits. Belg $\mathrm{J}$ Bot 129:157

Young A, Boyle T, Brown T (1996) The population genetic consequences of habitat fragmentation for plants. Trends Ecol Evol 11:413-418 